\title{
Growth Response to Weed Control and Fertilisation in Mid-Rotation Plantations of Eucalyptus pellita in South Sumatra, Indonesia
}

\author{
Maydra A. Inail ${ }^{1, *}$, Eko B. Hardiyanto ${ }^{2}$, Daniel S. Mendham ${ }^{3}\left(\mathbb{D}\right.$ and Erlanda Thaher ${ }^{1}$ \\ 1 PT. Musi Hutan Persada, Muara Enim, Prabumulih 31172, Indonesia; erlandathaher91@gmail.com \\ 2 Faculty of Forestry, Gadjah Mada University, Yogyakarta 55281, Indonesia; ebhardiyanto@ugm.ac.id \\ 3 CSIRO Land and Water, GPO Box 1700, Canberra, ACT 2601, Australia; Daniel.Mendham@csiro.au \\ * Correspondence: Maydra-AI@jpn.mhp.co.id
}

Citation: Inail, M.A.; Hardiyanto, E.B.; Mendham, D.S.; Thaher, E. Growth Response to Weed Control and Fertilisation in Mid-Rotation Plantations of Eucalyptus pellita in South Sumatra, Indonesia. Forests 2021, 12, 1653. https://doi.org/ $10.3390 /$ f12121653

Academic Editor: Luís González

Received: 26 October 2021

Accepted: 25 November 2021

Published: 29 November 2021

Publisher's Note: MDPI stays neutral with regard to jurisdictional claims in published maps and institutional affiliations.

Copyright: (c) 2021 by the authors. Licensee MDPI, Basel, Switzerland. This article is an open access article distributed under the terms and conditions of the Creative Commons Attribution (CC BY) license (https:// creativecommons.org/licenses/by/ $4.0 /)$.

\begin{abstract}
We report on a study of mid-rotation weed control and nutrient management in Eucalyptus pellita plantations in South Sumatra. The study was established at two contrasting sites (representing high and low productivity for the region) that had previously carried three rotations of Acacia mangium. A combination of weed control, nitrogen $(\mathrm{N})$, and phosphorus $(\mathrm{P})$ fertiliser were applied at 1 and 2 years after establishment. We found that the addition of up to $250 \mathrm{~kg} \mathrm{~N} \mathrm{ha}^{-1}$ applied either at 1 year or 2 years after planting did not improve growth. The application of $\mathrm{P}\left(30 \mathrm{~kg} \mathrm{P} \mathrm{ha}^{-1}\right)$ at age 1 year (in addition to $12 \mathrm{~kg} \mathrm{P} \mathrm{ha}^{-1}$ applied at planting) did not enhance tree growth either. Keeping the plantation free from weed competition throughout rotation (full weed control) enhanced wood volume up to age 4 years at the high-productivity site, while it improved wood volume up to the end of rotation at age 6 years at the low-productivity site. An additional experiment assessing the effect of weed control in the early phase of plantation establishment revealed that weed competition reduced young tree growth of E. pellita substantially. The results of the studies support the current practice of plantation management of E. pellita in the region that applied only P fertiliser at planting time and that kept trees free from weed competition before canopy closure. Full weed control throughout rotation is worth practicing at lower-productivity sites to achieve maximum productivity.
\end{abstract}

Keywords: nitrogen and phosphorus fertilisation; weed management; mid-rotation application; plantation productivity

\section{Introduction}

Eucalyptus pellita was introduced in Sumatra in early 1990s, but it was not planted on a large scale until the mid-2000s, when it replaced Acacia mangium. A. mangium had been the main species grown for pulp and paper for the previous two decades, but, in the third rotation, a fast-spreading canker-wilt disease caused by Ceratocystis fungi rendered A. mangium plantations no longer viable [1,2]. E. pellita has been found to be more resistant to Ceratocystis and is a good prospect for wood production, so it has become the species of choice in the region $[3,4]$.

The experience in growing E. pellita in large-scale plantations is new for managers in south and central Sumatra, but Eucalyptus plantations have been operationally planted in some parts of Sumatra for two to three decades. However, there is little information publicly available about the management of these plantations. In South Sumatra, the current growth rates of E. pellita are lower than that of A. mangium [3-5]. However, recent inventory data from operational plantings of $E$. pellita revealed that its productivity has improved due to better silviculture practices, including nutrient management and weed control [4]. It is likely that management practices need to be further refined to be able to achieve productivity levels similar to that of $A$. mangium.

All sites now planted with E. pellita in Sumatra were under acacia previously. Earlier studies with E. pellita established on sites previously grown with two to three rotations of 
A. mangium indicated that they only responded to phosphorus $(\mathrm{P})$ application but not to nitrogen $(\mathrm{N})$ application [3]. In this study, P fertiliser was applied at planting time, while $\mathrm{N}$ was given within one month after planting [3]. The application of fertiliser beyond the planting time (hereafter referred to as mid-rotation) has never been explored or reported on. The canopy of E. pellita stands tends to reach closure at around 9-14 months after planting, but then leaf area drops and the canopy remains open throughout the rest of the 6-7-year rotation. The cause of this loss of leaf area is not yet known, so we set out to understand if it was due to onset of macronutrient deficiency once slash and litter have fully decomposed and stopped contributing nutrients to the system. Reapplication of fertiliser in the mid-rotation and keeping the plantation free from weed competition over a whole rotation have never been carried out and may provide additional growth benefit to E. pellita.

We established an experiment with the key research questions to be addressed as follows: (i) does E. pellita respond to additional $\mathrm{P}$ and $\mathrm{N}$ fertilisers applied at 1 year after planting where leaf area appears to decline? (ii) Is there any benefit from weed control beyond one year of age as the light canopy of E. pellita may promote weed growth? (iii) How long is the critical period of weed interference? Our aim was to understand the value of mid-rotation nutrient and weed management for optimising the productivity of E. pellita plantations in this region.

\section{Materials and Methods}

\subsection{Study Site}

Four experiments were established consisting of two core mid-rotation experiments and two satellite experiments. One core experiment (Sodong) and two satellite experiments (Toman and Caban) were established in the Subanjeriji area, South Sumatra $\left(03^{\circ} 45^{\prime} 3^{\prime \prime} \mathrm{S}\right.$ and $103^{\circ} 54^{\prime} 41^{\prime \prime} \mathrm{E}$ ), while the 2nd core experiment was established in Lagan, South Sumatra $\left(03^{\circ} 35^{\prime} 41^{\prime \prime} \mathrm{S}\right.$ and $\left.103^{\circ} 36^{\prime} 27^{\prime \prime} \mathrm{E}\right)$. These sites belong to a forest company, PT Musi Hutan Persada (MHP). Sunarminto et al. [6] categorized the soil class in this region based on the depth to impeding (plinthite) layer: low productivity $(<50 \mathrm{~cm})$, medium productivity (50 to $100 \mathrm{~cm}$ ), and high productivity $(>100 \mathrm{~cm})$. Sodong represents a high-productivity site, while Lagan represents a low-productivity site (Table 1).

Table 1. Soil properties ( $0-20 \mathrm{~cm}$ depth) at mid-rotation experimental sites.

\begin{tabular}{|c|c|c|c|c|}
\hline \multirow[b]{2}{*}{ Variable } & \multicolumn{4}{|c|}{ Site } \\
\hline & $\begin{array}{l}\text { Core-Sodong } \\
\text { (Subanjeriji) }\end{array}$ & $\begin{array}{l}\text { Satellite-Toman } \\
\text { (Subanjeriji) }\end{array}$ & $\begin{array}{l}\text { Satellite-Caban } \\
\text { (Subanjeriji) }\end{array}$ & Core-Lagan \\
\hline Slope $(\%)$ & 1.75 & 1.40 & 5.77 & 9.01 \\
\hline Bulk density $0-20\left(\mathrm{~g} \mathrm{~cm}^{-3}\right)$ & 0.87 & 1.26 & 1.05 & 1.06 \\
\hline Depth to plinthite layer $(\mathrm{cm})$ & $>100$ & 76 & $>100$ & 50 \\
\hline Depth of A-horizon (cm) & 18 & 17 & 12 & 15 \\
\hline $\mathrm{pH}\left(\mathrm{H}_{2} \mathrm{O}\right)$ & 3.8 & 4.3 & 4.7 & 4.18 \\
\hline Soil organic carbon $(\%)$ & 3.23 & 4.23 & 3.00 & 1.80 \\
\hline $\mathrm{N}$ total $(\%)$ & 0.22 & 0.26 & 0.16 & 0.15 \\
\hline \multicolumn{5}{|l|}{ Soil textures (\%) } \\
\hline - Clay & 53.2 & 38.3 & 45.0 & 43.6 \\
\hline - Silt & 29.7 & 30.4 & 7.3 & 42.1 \\
\hline - Sand & 17.0 & 31.2 & 47.7 & 14.3 \\
\hline Cation exchange capacity $(\mathrm{CEC})\left(\mathrm{cmol} \mathrm{kg}^{-1}\right)$ & 12.1 & 13.3 & 9.5 & 12.2 \\
\hline Exchangeable $\mathrm{K}\left(\mathrm{mg} \mathrm{kg}^{-1}\right)$ & 65.2 & 62.6 & 66.5 & 66.9 \\
\hline Extractable P (mg kg $\left.{ }^{-1}\right)$ & 2.5 & 6.0 & 3.6 & 1.8 \\
\hline
\end{tabular}

The experiments were located at elevations ranging between $90 \mathrm{~m}$ to $110 \mathrm{~m}$ above sea level. The region has a tropical monsoonal climate characterised by mean annual temperature $>18{ }^{\circ} \mathrm{C}$, a short dry season, and heavy rainfall throughout the year [6]. During 
the experimental period, the average temperature was $27.6{ }^{\circ} \mathrm{C}$; the mean annual maximum and minimum temperatures were $32.3^{\circ} \mathrm{C}$ and $22.9^{\circ} \mathrm{C}$, respectively. The relative humidity ranged from 72 to $81 \%$. The average annual rainfall was $2359 \mathrm{~mm}^{-1} \mathrm{year}^{-1}$. The rainy season occurs from October to May with a monthly average rainfall during this time of $259 \mathrm{~mm}$. The dry season generally occurs from June to September with a monthly average rainfall of $74 \mathrm{~mm}$. The topography of the experimental sites is flat to slightly sloping (1.4-9.0\%). The soil of all sites is classified as Ultisols [7]. Soil (0-20 cm depth) was sampled from each replicate, with 10 cores taken systematically per replication and bulked. Samples were air-dried and sieved, and the fractions less than $2 \mathrm{~mm}$ were subsampled for analysis (Table 1). The upper 0-20-cm soil represents the depth to which most of the fine roots of Eucalypts are located and is a commonly used sampling depth to represent the active pools of plant nutrients.

\subsection{Site Preparation and Plantation Establishment}

All sites were prepared by manually re-distributing harvest residues from the previously harvested $A$. mangium stands evenly across all plots, followed by spraying emerging weeds with herbicides before planting. The soil was not tilled except for the manual planting of the trees. Vegetation prior to establishment comprised a mixture of grasses and Rolanda fruticosa and $A$. mangium wildings. All experiments were planted with seedlings grown from seeds harvested from a seedling seed orchard of Muting, Merauke (Papua, Indonesia) provenance.

\subsection{Experimental Design and Treatments}

The core experiments were established in January 2015 on sites that had previously carried three successive rotations of $A$. mangium. The experiments were installed using a randomised block design with five replications. Trees were planted at a spacing of $3 \times$ $2.5 \mathrm{~m}$ (1333 trees ha $\left.{ }^{-1}\right)$. Based on the experimental area available, each plot at Sodong contained 64 trees (36 measure trees and one buffer row surrounding the measure trees), while, at Lagan, it contained 49 trees (25 measure trees and one buffer row surrounding measure trees). For all treatments, seedlings were fertilised at planting with $\mathrm{P}\left(12 \mathrm{~kg} \mathrm{P} \mathrm{ha}^{-1}\right.$ as triple-super phosphate) as a basal fertiliser, which was applied at the base of the $20 \times 20$ $\times 20 \mathrm{~cm}$ planting hole. Weeds were controlled using a combination of manual slashing and herbicide spraying with glyphosate $\left(2.5 \mathrm{~L} \mathrm{ha}^{-1}\right)$ at an age of 3 months and glyphosate + metsulfuron-methyl (150 $\left.\mathrm{g} \mathrm{ha}^{-1}\right)$ at ages 6 and 12 months.

Treatments applied (Table 2) were designed to include the following comparisons:

- A factorial matrix of three rates of $\mathrm{N}\left(\mathrm{N} 0, \mathrm{~N} 125\right.$, and $\left.\mathrm{N} 250 \mathrm{~kg} \mathrm{ha}^{-1}\right)$ by two levels of weed control (up to age 1 year and for the full rotation). No additional $\mathrm{P}$ was applied in this matrix. In total, there were six treatments in the factorial mixture (Treatments 1-6).

- Additional treatments to explore the potential for further response to P fertiliser: (N125P30 and N0P30). Fertilisers were applied at age 1 year, and weed control was conducted throughout the rotation (Treatments 7-8).

- $\quad$ Additional treatments to test responses to two levels of N fertiliser (N125 and N250) were given at age 2 years. These treatments received full weed control throughout the rotation (Treatments 9-10).

Re-application of $P$ fertiliser was conducted by dividing it evenly into four and placing it at a $10-\mathrm{cm}$ depth into four holes at $1 \mathrm{~m}$ from tree base. $\mathrm{N}$ fertiliser was applied in a furrow 5-cm deep in between the tree rows, $1.5 \mathrm{~m}$ from the tree base. In full weed-control treatments, weed control was performed two times until two years of age then once a year until the end of rotation using the method applied at age 6 months. Prior to the implementation of mid-rotation treatments, the stocking rate ranged from 1110 to 1333 trees $\mathrm{ha}^{-1}$, the height from 3.6 to $4.9 \mathrm{~m}$, the diameter from 3.7 to $5.0 \mathrm{~cm}$, and the volume from 1.8 to $7.2 \mathrm{~m}^{3} \mathrm{ha}^{-1}$. 
Table 2. Mid-rotation management treatments applied in the core experiment.

\begin{tabular}{|c|c|c|c|c|c|}
\hline \multirow{5}{*}{ Treatment } & \multicolumn{4}{|c|}{ Fertilisation } & \multirow{5}{*}{ Weed Control * } \\
\hline & \multirow[t]{2}{*}{ Planting Time } & \multicolumn{3}{|c|}{ AT Age (Year) } & \\
\hline & & \multicolumn{2}{|c|}{1} & 2 & \\
\hline & P Fertiliser & P Fertiliser & N Fertiliser & N Fertiliser & \\
\hline & $\left(\mathrm{kg} P \mathrm{ha}^{-1}\right)$ & $\left(\operatorname{kg} P\right.$ ha $\left.{ }^{-1}\right)$ & $\left(k g N a^{-1}\right)$ & $\left(\operatorname{kg~N~ha} a^{-1}\right)$ & \\
\hline W1N0P0 & 12 & 0 & 0 & 0 & Full \\
\hline W1N125P0 & 12 & 0 & 125 & 0 & Full \\
\hline W1N250P0 & 12 & 0 & 250 & 0 & Full \\
\hline WONOP0 & 12 & 0 & 0 & 0 & Up to 1 year \\
\hline W0N125P0 & 12 & 0 & 125 & 0 & Up to 1 year \\
\hline W0N250P0 & 12 & 0 & 250 & 0 & Up to 1year \\
\hline W1N125P30 & 12 & 30 & 125 & 0 & Full \\
\hline W1N0P30 & 12 & 30 & 0 & 0 & Full \\
\hline $\mathrm{W} 1 \mathrm{~N} 125_{\mathrm{Age} 2} \mathrm{P} 0$ & 12 & 0 & 0 & 125 & Full \\
\hline $\mathrm{W} 1 \mathrm{~N} 250_{\mathrm{Age} 2} \mathrm{P0}$ & 12 & 0 & 0 & 250 & Full \\
\hline
\end{tabular}

* A combination of manual slashing and herbicide spraying.

The satellite experiments were established to better understand the response of $E$. pellita to weed control during the early phase of establishment. Satellite experiment- 1 , Toman (a medium-productivity site), was established in April 2014 at a site that had formerly carried three rotations of $A$. mangium. The spacing was $3 \times 2.5 \mathrm{~m}$. The treatment consisted of a factorial combination of three levels of weed control (no weed control, NWC; no weed control within the first 6 months, MWC; and full weed control until the end of rotation, FWC) and two levels of $\mathrm{P}\left(0\right.$ and $12 \mathrm{~kg} \mathrm{P} \mathrm{ha}^{-1}$, applied at planting time). The experiment was laid out as a randomised complete block design, with four replicates. Each plot contained 64 trees (36 measure trees, and one row of border trees).

Satellite experiment-2, Caban (a high-productivity site) was established in December 2017 on a site that had formerly carried three rotations of A. mangium and one rotation of E. pellita. The spacing was $3 \times 2 \mathrm{~m}$. The treatments comprised a factorial combination of two levels of P ( 0 and $33 \mathrm{~kg} \mathrm{P} \mathrm{ha}^{-1}$ applied at planting time, following the updated recommendations for operational plantings) and three levels of weed control: no weed control (NWC), no weed control at first 6 months (MWC), and full weed control until the end of rotation (FWC). The experiment was laid out as a randomised block design with four replicates. Each plot contained 49 trees ( 25 measure trees and one row of border trees).

\subsection{Measurements and Data Analysis}

The core experiments were assessed annually for the stem diameter at breast height $(D)$ and the total tree height $(H)$ until the end of rotation (6 years of age), whereas the satellite experiments were measured annually up to an age of 3 years. The satellite experiment at Toman was terminated at 3 years of age as the experiment was severely damaged by wildfire at 4 years of age. Individual stem volume, $v$, was calculated as:

$$
v=0.25 \pi D^{2} H F
$$

The form factor $(F)$ for E. pellita was 0.48 [8]. The total volume per ha $(V)$ for each treatment was the sum of the individual tree volume $(v)$ per plot converted to a per-hectare basis. The productivity loss was expressed as the percentage difference in volume between non-full-weed-control treatment compared to that of the full-weed-control treatment.

The aboveground weed biomass was estimated by collecting weed biomass at Toman, at age 6 and 12 months using five $1-\mathrm{m}^{2}$ sampling plots systematically placed in each plot. 
Weed samples were dried at $76{ }^{\circ} \mathrm{C}$ to a constant weight. The dry weight of weed biomass per plot was scaled up to estimate the weed biomass per hectare.

In the core experiment, as the differences in growth and survival between plots within replication at an age of 1 year (before applying mid-rotation treatment) were significant, analyses of covariance (ANCOVA) were performed using the plot mean of height, the diameter, and the total volume measured at age 1 year as respective covariates to increase precision. In the satellite experiment, a two-way analysis of variance (ANOVA) was performed, followed by Duncan's multiple range test at $\alpha=0.05$ if differences between treatments were significant. All analyses were conducted using R.ver. 4.1.1 software.

\section{Results}

\subsection{Response to Fertiliser and Weed-Control Treatment in Mid-Rotation}

Survival rates were considered satisfactory across all treatments and sites with regard to the current practice of growing E. pellita in the region. Survival rates in the core experiment at age 6 years ranged from 74.0 to $78.3 \%$ at Sodong and from 73.5 to $83.0 \%$ at Lagan. At Sodong the growth was faster than at Lagan in any treatment applied (Table 3). At Sodong the mean annual increment (MAI) varied between 31.5 and $33.6 \mathrm{~m}^{3} \mathrm{ha}^{-1}$ year $^{-1}$, while at Lagan it varied between 24.3 and $28.6 \mathrm{~m}^{3} \mathrm{ha}^{-1}$ year $^{-1}$.

Table 3. Growth and survival of Eucalyptus pellita at mid-rotation in the core experiment at age 6 years.

\begin{tabular}{|c|c|c|c|c|c|c|}
\hline Site & Treatment & Level & Height, $H$ (m) & $\mathrm{DBH}, D(\mathrm{~cm})$ & Volume, $V\left(\mathrm{~m}^{3} \mathrm{ha}^{-1}\right)$ & Survival (\%) \\
\hline \multirow[t]{16}{*}{ Sodong } & & \multicolumn{5}{|c|}{ Application of $N$ at 1 year and weed control } \\
\hline & $\mathrm{N}$ fertiliser & 0 & 19.6 & 15.4 & 193.3 & 76.0 \\
\hline & $\left(\mathrm{kg} \mathrm{ha}^{-1}\right)$ & 125 & 19.2 & 14.8 & 190.4 & 76.5 \\
\hline & & 250 & 20.2 & 15.6 & 203.7 & 74.1 \\
\hline & & $p$-value & 0.15 & 0.13 & 0.60 & 0.82 \\
\hline & Weed control & $<1$ year $(\mathrm{W} 0)$ & 19.4 & 15.0 & 190.6 & 77.0 \\
\hline & & Full (W1) & 19.9 & 15.5 & 201.1 & 74.0 \\
\hline & & $p$-value & 0.24 & 0.18 & 0.39 & 0.36 \\
\hline & & \multicolumn{5}{|c|}{ Application of $P$ at 1 year with full weed control } \\
\hline & P fertiliser & 0 & 19.2 & 15.2 & 201.5 & 78.3 \\
\hline & $\left(\mathrm{kg} \mathrm{ha}^{-1}\right)$ & 30 & 20.0 & 15.7 & 210.8 & 75.1 \\
\hline & & $p$-value & 0.11 & 0.23 & 0.47 & 0.60 \\
\hline & & \multicolumn{5}{|c|}{ Timing of $N$ application } \\
\hline & Age (year) & 1 & 20.0 & 15.3 & 193.7 & 74.5 \\
\hline & & 2 & 19.9 & 15.5 & 211.0 & 73.1 \\
\hline & & $p$-value & 0.92 & 0.51 & 0.42 & 0.74 \\
\hline \multirow[t]{16}{*}{ Lagan } & & \multicolumn{5}{|c|}{ Application of $N$ at 1 year and weed control } \\
\hline & $\mathrm{N}$ fertiliser & 0 & 18.0 & 14.4 & 151.4 & 73.5 \\
\hline & $\left(\mathrm{kg} \mathrm{ha}^{-1}\right)$ & 125 & 17.7 & 14.0 & 164.4 & 83.0 \\
\hline & & 250 & 18.2 & 14.0 & 155.9 & 77.5 \\
\hline & & $p$-value & 0.54 & 0.31 & 0.36 & 0.01 \\
\hline & Weed control & $<1$ year $(\mathrm{W} 0)$ & 17.6 & 14.0 & 146.0 & 76.2 \\
\hline & & Full (W1) & 18.2 & 14.3 & 168.5 & 79.8 \\
\hline & & $p$-value & 0.15 & 0.27 & 0.01 & 0.14 \\
\hline & & \multicolumn{5}{|c|}{ Application of $P$ at 1 year with full weed control } \\
\hline & P fertiliser & 0 & 18.3 & 14.4 & 171.5 & 78.5 \\
\hline & $\left(\mathrm{kg} \mathrm{ha}^{-1}\right)$ & 30 & 18.7 & 14.7 & 165.1 & 73.1 \\
\hline & & $p$-value & 0.40 & 0.41 & 0.70 & 0.13 \\
\hline & & \multicolumn{5}{|c|}{ Timing of $N$ application } \\
\hline & Age (year) & 1 & 18.1 & 14.1 & 173.8 & 79.9 \\
\hline & & 2 & 18.6 & 15.1 & 169.6 & 77.1 \\
\hline & & $p$-value & 0.13 & 0.09 & 0.74 & 0.63 \\
\hline
\end{tabular}


At age 6 years, $\mathrm{N}$ addition up to $250 \mathrm{~kg} \mathrm{ha}^{-1}$ applied at one year after planting did not increase growth (height, diameter, and volume) significantly at either Sodong or Lagan. The timing of $\mathrm{N}$ application (at age 1 or 2 years) up to $250 \mathrm{~kg} \mathrm{ha}^{-1}$ also did not affect growth (height, diameter, and volume) significantly at Sodong or Lagan. These findings suggest that $\mathrm{N}$ was not limiting E. pellita productivity in this study, even at sites with contrasting productivity.

At Sodong, differences between weed-control treatments were only significant for a stem diameter up to age 4 years $(p=0.05)$, with stands receiving weed treatment beyond 1 year of age (full weed control) having a larger diameter than those receiving weed control up to age 1 year (Table 3). However, the effect of weed control on diameter had dissipated by the end of rotation at age 6 years. The weed-control treatment did not significantly affect the survival rate. Similarly, at Lagan, differences between weed treatments were significant for the diameter $(p=0.003)$ and the volume $(p=0.008)$ up to age 4 years; stands receiving weed treatment beyond age 1 year had larger diameters and volumes than those receiving weed control up to age 1 year. The effect of weed control remained significant for volume ( $p=0.015)$ up to the rotation end. At Lagan, the weed control treatment did not significantly affect the survival rate. The volume loss of receiving weed control up to age 1 year at Lagan was higher than Sodong by $13.4 \%$ compared to $5.2 \%$ at the age of 6 years (Figure 1). Nevertheless, there was a tendency for higher productivity at the end of the rotation under full weed control at Sodong and Lagan. Interactions between weed control and $\mathrm{N}$ addition were not significant for all growth characteristics in the entire rotation, indicating that weeds were not competing with the eucalypts for $\mathrm{N}$.

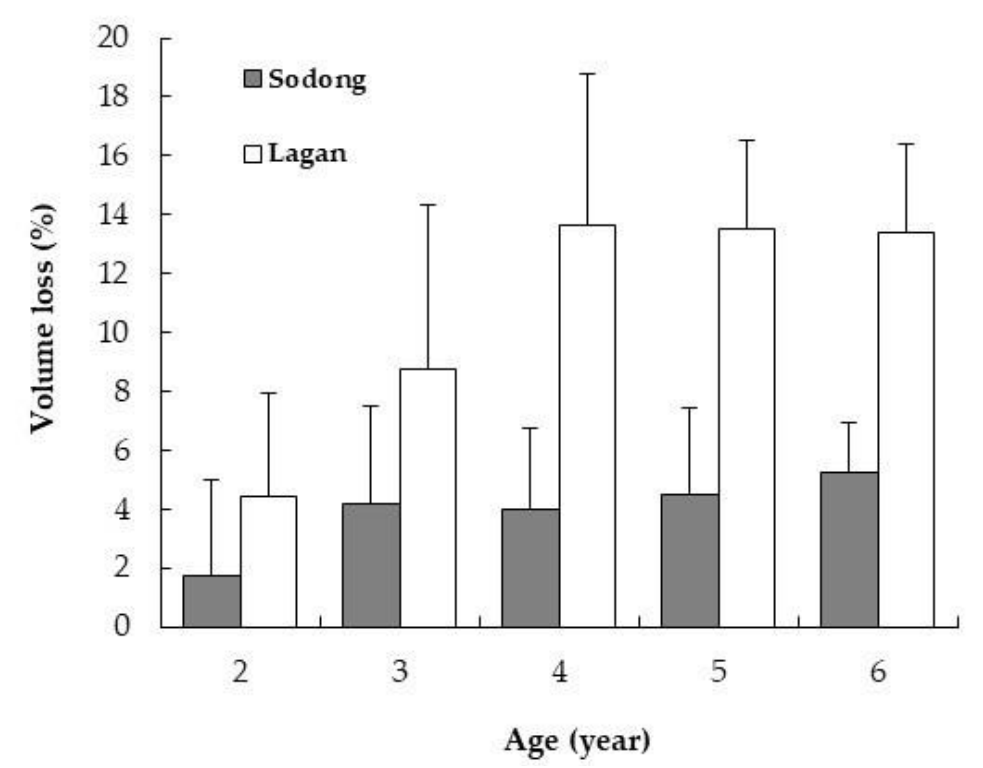

Figure 1. Volume loss of Eucalyptus pellita due to less-intensive weed control (up to age 1 year) compared with more-intensive weed control (up to harvest age) at Sodong (high-productivity site) and Lagan (low-productivity site). Error bars represent SE of means.

The application of $\mathrm{P}$ alone or combined with $\mathrm{N}$ at mid-rotation did not increase tree growth (height, diameter, or volume) significantly in the entire rotation at Sodong and Lagan, suggesting that the application of $P$ beyond the planting time was not effective in enhancing E. pellita growth in this study. The growth response to the additional $\mathrm{P}$ was not dependent on the addition of $\mathrm{N}$ given at age 1 year (Table 3 ).

\subsection{Response to Weed Control and P Applied at Planting Time}

At 3 years of age in the satellite sites, survival ranged from 87.5 to $97.8 \%$ at Toman and between $77.0 \%$ and $88.3 \%$ at Caban. P fertiliser applied at planting time increased growth 
significantly by age 1.5 year (height, $p<0.001$; diameter $p<0.001$; volume, $p<0.001$ ) at Toman and Caban; this remained significant at 3 years of age at both sites (Table 4 ).

Table 4. Growth response of Eucalyptus pellita at 3 years to weed control and P fertiliser applied at planting time.

\begin{tabular}{|c|c|c|c|c|c|}
\hline \multirow{2}{*}{ Site } & \multirow{2}{*}{ Variable } & \multirow{2}{*}{ Level } & Height, $H$ & DBH, $D$ & Volume, $V$ \\
\hline & & & (m) & $(\mathrm{cm})$ & $\left(m^{3} h a^{-1}\right)$ \\
\hline \multirow[t]{7}{*}{ Toman } & \multirow{4}{*}{$\begin{array}{l}\text { Weed control } \\
\text { (W) }\end{array}$} & NWC & $11.1 \mathrm{a}$ & $9.6 \mathrm{a}$ & $56.2 \mathrm{a}$ \\
\hline & & MWC & $11.6 \mathrm{ab}$ & $10.0 \mathrm{a}$ & $63.0 \mathrm{ab}$ \\
\hline & & FWC & $12.1 \mathrm{~b}$ & $10.9 \mathrm{~b}$ & $71.7 \mathrm{~b}$ \\
\hline & & $p$-value & 0.048 & $<0.001$ & $<0.001$ \\
\hline & \multirow{3}{*}{$\begin{array}{l}\text { P fertiliser } \\
\left(\mathrm{kg} \mathrm{ha}^{-1}\right)\end{array}$} & 0 & 10.8 & 9.5 & 53.1 \\
\hline & & 12 & 12.4 & 10.9 & 74.1 \\
\hline & & $p$-value & $<0.001$ & $<0.001$ & $<0.001$ \\
\hline \multirow[t]{7}{*}{ Caban } & \multirow{4}{*}{$\begin{array}{l}\text { Weed control } \\
\text { (W) }\end{array}$} & NWC & $8.7 \mathrm{a}$ & $5.9 \mathrm{a}$ & $25.1 \mathrm{a}$ \\
\hline & & MWC & $11.9 \mathrm{~b}$ & $9.4 \mathrm{~b}$ & $68.6 \mathrm{~b}$ \\
\hline & & FWC & $12.8 \mathrm{~b}$ & $9.8 \mathrm{~b}$ & $78.4 \mathrm{~b}$ \\
\hline & & $p$-value & $<0.001$ & $<0.001$ & $<0.001$ \\
\hline & \multirow{3}{*}{$\begin{array}{l}\text { P fertiliser } \\
\left(\mathrm{kg} \mathrm{ha}^{-1}\right)\end{array}$} & 0 & 9.7 & 7.1 & 39.4 \\
\hline & & 33 & 12.6 & 9.6 & 75.3 \\
\hline & & $p$-value & $<0.001$ & $<0.001$ & $<0.001$ \\
\hline
\end{tabular}

Note: interactions between weed control and the rate of P fertiliser were not significant at all sites. Means having the same letter were not significantly different according to Duncan's multiple range test at $\alpha=0.05$.

At age 1.5 years, weed control significantly influenced growth at Toman (height, $p<0.05$; diameter, $p<0.001$; and volume, $p<0.001$ ) and at Caban (height, $p<0.001$; diameter, $p<0.001$; and volume, $p<0.001$ ). The effect of weed control on growth remained significant at 3 years of age at both sites; FWC resulted in faster growth than NWC and MWC. Interactions between weed-control treatments and $\mathrm{P}$ application were not significant at both sites, suggesting that weeds were not competing with the Eucalyptus crop for $\mathrm{P}$ (Table 4).

Weed biomass accumulation between NWC and FWC differed significantly at age 6 months $(p<0.01)$ and 12 months $(p<0.05)$. At age 6 months, the weed biomass in NWC treatment was higher (3.4 tonnes ha ${ }^{-1}$ ) than the FWC plot $\left(1.6\right.$ tonnes ha $\left.{ }^{-1}\right)$; it was 4.9 tonnes ha ${ }^{-1}$ and 3.5 tonnes ha ${ }^{-1}$ in the NWC and FWC treatments, respectively, at 12 months of age (Figure 2). The impact of weed competition on growth in the first 1.5 years after planting was substantial; it decreased volume markedly at Caban and Toman (Figure 3). At age 1.5 years, the volume losses due to less-intensive weeding (MWC) compared with intensive weeding (FWC) were $30.2 \%$ and $38.1 \%$ at Caban and Toman, respectively; the volume losses decreased with age, i.e., $12.5 \%$ and $12.2 \%$ at age 3 years at Caban and Toman, respectively (Figure 3a). A lack of weed control (NWC) resulted in very high volume losses at both sites. At Toman, the volume loss decreased with age, from $54.1 \%$ at age 1.5 years to $21.6 \%$ at age 3.0 years. In contrast, at Caban it tended to increase with age, namely, from $54.9 \%$ at age 1.5 years to $67.9 \%$ at age 3 years. It is worth noting that the competing weeds differed between the two sites. At Toman, it was dominated by grasses, particularly Cyrtococcum sp., while, at Caban, it consisted of a mixture of Imperata cylindrica, a hardy weed, Rolanda fruticose, and A. mangium wildings. 


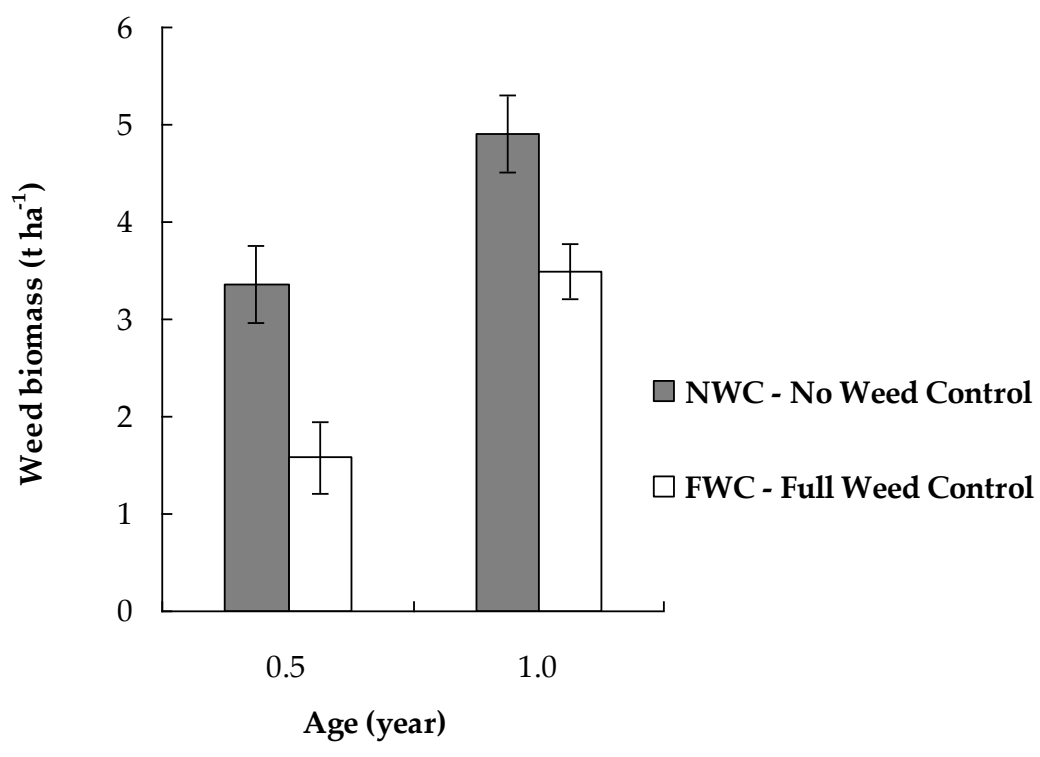

Figure 2. Weed biomass with different levels of weed control under Eucalyptus pellita plantation at Toman. Vertical bars are SE of means.

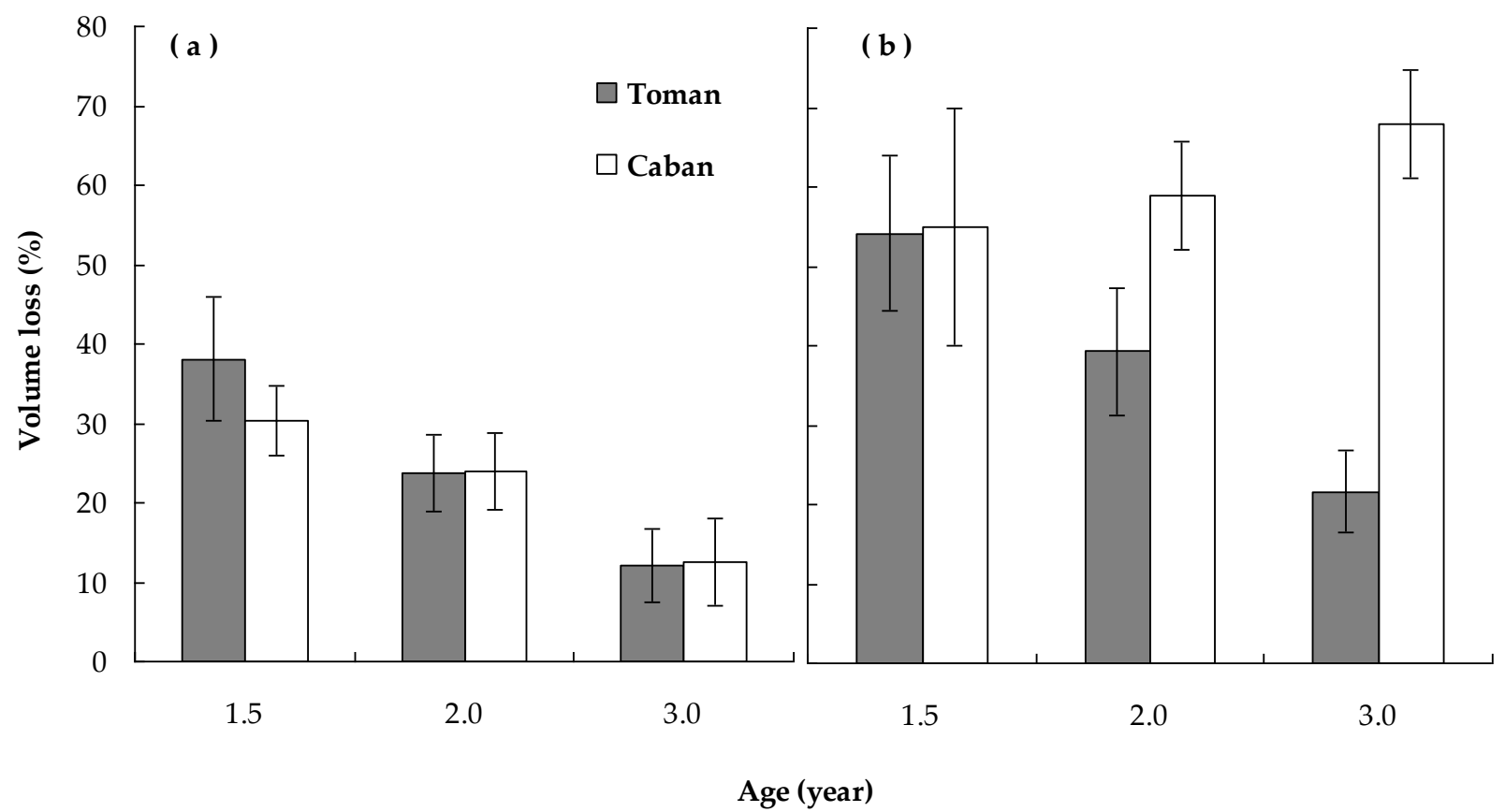

Figure 3. Volume loss in E. pellita due to (a) less-intensive weed control (MWC) compared with more-intensive weed control (FWC); (b) no weed control (NWC) compared with more-intensive weed control (FWC) at Toman and Caban. Vertical bars are SE of means.

\section{Discussion}

\subsection{Influence of Fertilisation in Mid-Rotation on Productivity}

The core experiments demonstrated that the addition of $\mathrm{N}$ fertiliser applied at midrotation was ineffective at supporting additional growth of E. pellita at the study sites. It only increased growth slightly and not significantly (height, 1-3\%; diameter 2\%; and volume $3-5 \%$ ). It seems that the amount of $\mathrm{N}$ in the soil at the study sites was adequate to support current growth of E. pellita at both sites despite Lagan having a lower productivity (Table 1). This is probably due to the previous rotations of A. mangium, an N-fixing species with a high capacity to fix atmospheric $N$, with Wibisono et al. [9] finding N-fixation rates 
of $200 \mathrm{~kg} \mathrm{~N} \mathrm{ha}^{-1}$ within 18 months. The presence of $A$. mangium wildings under E. pellita stand possibly also contributed to the $\mathrm{N}$ stock in the soil, although the contribution of wildlings to site $\mathrm{N}$ pools had not been quantified.

Another potential reason for the lack of responsiveness to $\mathrm{N}$ at 1-2 years may be because of increased soil mineralisation. Across five sites in South Sumatra, Mendham et al. [10] found that $\mathrm{N}$ mineralisation increased with increasing stand age, from near zero at age 1 up to 10 to $50 \mathrm{mg} \mathrm{kg}^{-1}$ soil 28 days $^{-1}$ at age 2 years. $\mathrm{N}$ mineralisation of eucalyptus plantation on clay soil (0-20 cm soil depth) in Brazil was reported to be very high, ranging from 110 to $207 \mathrm{~kg} \mathrm{ha}^{-1}$ year $^{-1}$ [11]. The high $\mathrm{N}$ mineralisation of soil organic matter provided adequate $\mathrm{N}$ to support optimal growth throughout rotation.

Mid-rotation fertiliser application in eucalyptus plantation reported from various studies have found inconsistent results. Eucalyptus grandis responded to mid-rotation application of up to $250 \mathrm{~kg} \mathrm{~N} \mathrm{ha}^{-1}$ at two of six sites in Colombia, with the two responsive sites both having low foliar $\mathrm{N}$ concentrations [12]. In Brazil, any growth response to $\mathrm{N}$ applied to 11 sites (up to $240 \mathrm{~kg} \mathrm{ha}^{-1}$ at 6-18 months) had completely dissipated at the end of rotation at 6 years of age [11]. In contrast, an application of N-fertiliser (up to $160 \mathrm{~kg} \mathrm{~N} \mathrm{ha}^{-1}$ ) to E. grandis in South Africa significantly improved growth, and the response was sustained until the end of rotation at age 8.3 years [13]. The strong positive response to the mid-rotation $\mathrm{N}$ application reported in that study occurred because the experiment was carried out in poor stands growing on an infertile soil.

It has been well documented that the addition of $\mathrm{P}$ at planting time markedly improves the early growth of E. pellita and that the growth response is sustained towards the end of rotation, although the proportional response declines over time [3,4]. In contrast, we found that application of $P$ at age 1 year (in addition to $P$ fertiliser given at establishment) did not result in any further additional growth of E. pellita throughout the rotation. Similar findings were reported from a mid-rotation fertiliser study with Eucalyptus nitens in Chile, where addition of $\mathrm{P}$ ( up to $60 \mathrm{~kg} \mathrm{ha}^{-1}$ ) post-establishment did not enhance tree growth by 3 years of age [14]. Similarly, a mid-rotation fertiliser application of $300 \mathrm{~kg}$ NPK ha $^{-1}(42.0 \mathrm{~N}: 27.6 \mathrm{P}: 52.5 \mathrm{~K})$ applied at 5 years of age in a Eucalyptus globulus plantation in Portugal did not significantly improve growth at 7 years after application [15].

The non-existent response to $\mathrm{P}$ addition at mid-rotation in E. pellita demonstrated that trees did not require an external $\mathrm{P}$ supply to support their growth after canopy closure. The highest annual rate and requirement for P uptake in E. pellita occurred in the first year and then declined after 2 years of age [3]. Similarly, Laclau et al. [16] reported that 50-65\% of the maximum nutrient requirements in a eucalyptus plantation in Congo occurred in the first year. During the early tree-growth stage where the rooting system is not yet fully established, and while the crown is developing rapidly, external nutrient input is required to meet the high demand. This is particularly relevant where the available P in soil is low, such as in our experiment (Table 1).

After canopy closure, the response to external nutrient input diminishes over time. The lack of response and decline in response to $\mathrm{P}$ fertiliser applied at 1 year after planting is influenced by high internal nutrient retranslocation rates for $\mathrm{P}(54.6-73.2 \%), \mathrm{N}(24.9-33.0 \%)$, and K (40.2-49.0\%), while there was minimal retranslocation of $\mathrm{Ca}$ and $\mathrm{Mg}$ [17]. External cycling through litter after canopy closure is also important, with litterfall of E. pellita at Sodong being measured at $8.7 \pm 0.4 \mathrm{Mg} \mathrm{ha}^{-1}$ year $^{-1}$ [4]. Litter decomposition of E. pellita in this environment was rapid, with $91.0 \%$ of leaves, $71.0 \%$ of twigs, and $71.2 \%$ of noncommercial stems (diameter $<5 \mathrm{~cm}$ ) being completely decomposed within 18 months [18]. Based on annual litterfall production from age of 1 to 6 years, the mean rates of nutrient accumulation were estimated to be $48.8 \mathrm{~kg} \mathrm{~N} \mathrm{ha}^{-1} \mathrm{year}^{-1}, 1.5 \mathrm{~kg} \mathrm{P} \mathrm{ha}^{-1}$ year $^{-1}$, and $17.2 \mathrm{~kg} \mathrm{~K} \mathrm{ha}{ }^{-1}$ year $^{-1}[17]$.

\subsection{Effect of Weed Competition on Tree Growth}

During the early phase of plantation establishment, weed competition reduced the growth of E. pellita substantially at Caban (high-productivity site) and Toman (medium- 
productivity site). In general, proportional growth reduction was high before canopy closure (less than 1 year old) and gradually declined with age. The continued response to weed control at Caban is likely due to the competing weed species at this site. At Toman, grasses were suppressed as the stand aged, while the hardy weed of $R$. fruticosa and $A$. mangium wildings at Caban kept growing and competing with E. pellita for available resources when the weeds were not managed well (Figure 3 ). The adverse effect of weed competition on growth during the early phase of plantation establishment of eucalyptus has been well documented, and it is no exception for E. pellita [19-24].

This study is the first to report on the effect of weed control after canopy closure (beyond 1 year after planting) on E. pellita plantation productivity. We found that growth responses to the weed control beyond 1 year differed at the two contrasting sites. At Sodong (high-productivity site), the effect of continued weed control was not significant at the end of rotation despite the potential volume loss of about $5 \%$. Trees at this site seemed to have a sufficient supply of nutrients and water to support optimal growth, even though there were significant weed loads at that site where they were not controlled. In contrast, a sustained wood volume response to weed removal throughout the rotation occurred at Lagan (low-productivity site) with a potential volume loss of around $13 \%$ when the weed control was implemented only up to an age of 1 year compared with full-weed control throughout rotation (Figure 1). Sustained growth responses to weed control throughout rotation have been reported in other Eucalyptus plantations [21,22,25].

The slower growth rate at Lagan was associated with a combination of a shallower rooting depth and a higher intensity of weed competition. The lower plantation productivity of many sites in this region had been attributed to the presence of a plinthite or gley layer in the soil $[4,26]$, such as that at Lagan where the depth to plinthite was less than $50 \mathrm{~cm}$ (Table 1). The increase in Eucalyptus growth in response to continued weed control has been explained by a reduced competition for water [25] and nutrients [19,24], though it should be noted that our experiment did not suggest any competition for $\mathrm{N}$ or $\mathrm{P}$ was the source of the growth reduction in non-weeded treatments. Competition for water may be higher in areas with less rooting depth in the dry months. In South Sumatra, soil moisture content and soil water depletion varied and were strongly influenced by shallow groundwater, especially in the dry season [27].

\subsection{Implications and Challenges for Operational Plantations}

This study demonstrated that the application of fertiliser (N and $\mathrm{P}$ ) at mid-rotation (beyond planting time) was ineffective in enhancing growth at either a high- or lowproductivity site in South Sumatra. This finding strongly supports the current practice of fertiliser management for E. pellita in this region, namely, that $\mathrm{P}$ fertiliser need only be applied at planting time and that no addition of $\mathrm{N}$ is required on these sites. At poor sites, characterised by a shallow impeding (plinthite) layer and not constrained by nutrient availability to support optimal growth, trees required a more-intensive weed control to enhance plantation productivity; slower tree growth and a longer time to reach canopy closure provide a favourable environment for weeds to grow more vigorously. There are a number of other management options that may increase the productivity of poor sites. Among others, they include: (1) improving the growth rate by tree breeding and selection of high-performing clones, (2) developing coppice plantations, and (3) accelerating the time to canopy closure by increasing the initial stocking density at planting time.

E. pellita is an easy species to be vegetatively propagated using shoot cutting and offers the opportunity for clonal plantation development with high productivity. The yield trial involving a number of selected clones adapted to a poor site in South Sumatra has shown a good promise for the development of the high plantation productivity of E. pellita $[9,28]$. E. pellita has a high capacity to coppice after being harvested, and coppice plantation had a substantially higher growth rate than that of seedlings even at a poor site. At age 5 years, the height, diameter, and volume of coppice plantation were $18.2 \mathrm{~m}, 14.2 \mathrm{~cm}$, and $208.3 \mathrm{~m}^{3} \mathrm{ha}^{-1}$, respectively, while the corresponding values of seedling plantation were 
$15.6 \mathrm{~m}, 11.7 \mathrm{~cm}$, and $104.2 \mathrm{~m}^{3} \mathrm{ha}^{-1}$, respectively [29]. Tree stocking has been identified to be strongly associated with harvested wood volume for short-rotation E. pellita. The stocking rate of E. pellita plantation found in this study and reported from a previous study [4] steadily declined towards the end of rotation, suggesting that it is critical to establish plantation at a density (spacing distance) that ensures high stocking remains by harvest age. The initial tree density of 1666 trees ha $^{-1}$ was reported to be optimal for the current seedling planting material, as it yielded high wood volume per hectare without reducing the mean diameter significantly [30].

The full weed-control treatment only significantly improved productivity at the lowquality site, so full weed control may only need to be stringently applied at low-quality sites. However, weed control is also important for fire management, and keeping the plantation with a low weed biomass is a key method for preventing fire incidence, either due to wildfire or human-induced fire, both of which are quite common in the dry season in the region.

\section{Conclusions}

This is the first study to report on the response of E. pellita to mid-rotation $\mathrm{N}$ and $\mathrm{P}$ fertiliser application, and its interactions with weed control after conversion of the sites from A. mangium. The results were clear: $\mathrm{N}$ fertiliser applied either at 1 year or 2 years after planting did not enhance E. pellita growth. Full weed control throughout rotation improved wood volume at the low-quality site, while weed control up age 1 year was sufficient to achieve high wood volume at the high-quality site. The addition of $30 \mathrm{~kg} \mathrm{ha}^{-1}$ of $\mathrm{P}$ applied at 1 year after establishment (in addition to basal $\mathrm{P}$ given at planting time) was ineffective in increasing E. pellita growth at two contrasting sites, suggesting that the current $P$ fertiliser application at planting time remains sufficient to support the optimal growth of E. pellita. Weed control at the early-phase plantation establishment is very critical for tree growth at all sites, but full weed control throughout rotation is only important for productivity at low-quality sites. The results of the study have practical implications for fertiliser and weed-management strategies in E. pellita plantations in this region that may be adopted by plantation managers. $P$ fertiliser application must be at establishment and cannot be delayed until mid-rotation at both high- and low-productivity sites to achieve optimal growth. Additionally, an effective weed management strategy differs between two sites where full weed control needs to be applied at low-productivity sites throughout rotation to increase wood volume production, but, at higher-productivity sites, weed control after canopy closure does not need to be as rigorously applied as it does not significantly improve productivity. As the current E. pellita plantations were established on ex-A. mangium sites, the $\mathrm{N}$ status was high, but the requirement for $\mathrm{N}$ fertiliser application in future rotations of E. pellita (a non-N-fixing species) remains unknown. The $\mathrm{N}$ status and responsiveness of E. pellita needs to be monitored into the future.

Author Contributions: Conceptualization, D.S.M., E.B.H. and M.A.I.; methodology, E.B.H., D.S.M.; validation, E.B.H., M.A.I. and D.S.M.; formal analysis E.B.H. and M.A.I.; investigation, E.B.H., M.A.I., D.S.M. and E.T.; data curation, M.A.I., E.B.H. and E.T.; writing-original draft preparation, M.A.I. and E.B.H.; writing—review and editing E.B.H. and D.S.M.; project administration, M.A.I., E.B.H. and D.S.M.; funding acquisition, D.S.M., E.B.H. and M.A.I. All authors have read and agreed to the published version of the manuscript.

Funding: This research was financially supported by Australian Centre for International Agricultural Research (ACIAR) for funding the study through ACIAR Project FST/2014/064 and by PT Musi Hutan Persada, South Sumatra.

Data Availability Statement: Data are unavailable.

Acknowledgments: The authors are extremely grateful to the Australian Centre for International Agricultural Research (ACIAR) for funding the study through ACIAR Project FST/2014/064 and to the management of PT Musi Hutan Persada for their commitment to its implementation. We also thank R\&D General Manager and Silviculture Team at the Research and Development, PT. Musi 
Hutan Persada for various support, assistance in experimental works, long-term maintenance, and data collection. We thank two anonymous reviewers for their valuable comments and suggestions on the manuscript.

Conflicts of Interest: The authors declare no conflict of interest.

\section{References}

1. Tarigan, M.; Roux, J.; van Week, M.; Tjahjono, B.; Wingfield, M.J. A new wilt and die-back disease of A. mangium associated with Ceratocystis manginecans and C. acaciicvora sp. nov. in Indonesia. S. Afr. J. Bot. 2010, 77, 292-304. [CrossRef]

2. Nasution, A.; Glen, M.; Beadle, C.; Mohammed, C. Ceratocystis wilt and canker-A disease that compromises the growing of commercial Acacia-based plantations in the tropics. Aust. For. 2019, 82, 80-93. [CrossRef]

3. Inail, M.A.; Hardiyanto, E.B.; Mendham, D.S. Growth responses of Eucalyptus pellita F. Muell plantations in South Sumatra to macronutrient fertilisers following several rotations of Acacia mangium willd. Forests 2019, 10, 1054. [CrossRef]

4. Hardiyanto, E.B.; Inail, M.A.; Nambiar, E.K.S. Productivity of Eucalyptus pellita in Sumatra: Acacia mangium Legacy, Response to Phosphorus, and Site Variables for Guiding Management. Forests 2021, 12, 1186. [CrossRef]

5. Harwood, C.E.; Nambiar, E.K.S. Productivity of acacia and eucalypt plantations in Southeast Asia. 2. Trends and variations. Int. For. Rev. 2014, 16, 249-260. [CrossRef]

6. Sunarminto, B.H.; Kertonogoro, B.D.; Purwanto, B.H.; Shiddieq, D.; Syukur, A.; Sulakhudin Hatta, M.; Rif'an, M. Soil Mapping and Survey of Region Forest Group PT.MHP South Sumatera; Soil Science Departement, Faculty of Agriculture, Gadjah Mada University: Yogyakarta, Indonesia, 2012; p. 10.

7. Soil Survey Staff. Keys to Soil Taxonomy, 12th ed.; USDA-Natural Resources Conservation Service: Washington, DC, USA, 2014; p. 359.

8. Supriadi, B. Form factor of Eucalyptus pellita. Technical Notes R\&D. PT Musi Hutan Persada 2011, 21, 1-5.

9. Wibisono, M.G.; Veneklaas, E.; Mendham, D.S.; Hardiyanto, E.B. Nitrogen fixation of Acacia mangium Willd. from two seed sources grown at different levels of phosphorus in an Ultisol, South Sumatra, Indonesia. Southern Forests. J. For. Sci. 2015, 77, 59-64.

10. Mendham, D.S.; Greenhill, M.; Beadle, C.; Hardiyanto, E.; Wibisono, G.; Rimbawanto, A.; Fauzi, A.; Dong, T.L.; Huong, V.D.; Hai, T.A.; et al. Maximising Productivity and Profitability of Eucalypts and Acacias in Indonesia and Vietnam; Final Report of FST/2014/064; Australian Centre for Agricultural Research: Canberra, QT, Australia, 2020; p. 30.

11. Pulito, A.P.; Goncalves, J.L.M.; Smethurst, P.J.; Arthur-Junior, J.C.; Alvares, C.A.; Rocha, J.H.T.; Hubner, A.; de Moraes, L.F.; Miranda, A.C.; Kamogawa, M.Y.; et al. Available nitrogen and responses to nitrogen ferilizer in Brazilian Eucalypt plantations on Soils of contrasting texture. Forests 2015, 6, 973-991. [CrossRef]

12. Albaugh, T.J.; Rubilar, R.A.; Fox, T.R.; Lee Allen, H.; Urrego, J.B.; Zapata, M.; Stape, J.L. Response of Eucalyptus grandis in Colombia to mid-rotation fertilization is dependent on site and rate but not frequency of application. For. Ecol. Manag. 2015, 350, 30-39. [CrossRef]

13. Du Toit, B.; Arbuthnot, A.; Oscroft, D.; Job, R.A. The effect of remedial fertilizer treatments on growth and pulp properties of Eucalyptus grandis stands established on infertile soils of the Zululand coastal plain. S. Afr. For. J. 2001, 192, 9-19.

14. NC State University. Forest Productivity Cooperative, Shaping the Future of Plantation Forestry. In Effects of N and P Fertilization Post-Establishment on Growth of Eucalyptus nitens Plantations in the South-Central Chile; Eucalyptus Forestry Summaries 2014; NC State University: Raleigh, NC, USA, 2019; Volume 2, pp. 15-16.

15. Carneiro, M.; Fabiao, A.; Martins, M.C.; Fabiao, A.; da Silva, M.A.; Hilario, L.; Lousa, M.; Madeira, M. Effects of harrowing and fertilisation on understory vegetation and timber production of a Eucalyptus globulus Labill. Plantatation in Central Portugal. For. Ecol. Manag. 2008, 255, 591-597. [CrossRef]

16. Laclau, J.P.; Ranger, J.; Gonçalves, J.L.M.; Maquere, V.; Krusche, A.V.; M’bou, A.T.; Nouvellon, Y.; Saint-Andre, L.; Bouillet, J.P.; Piccolo, M.C.; et al. Biogeochemical cycles of nutrients in tropical Eucalyptus plantations Main features shown by intensive monitoring in Congo and Brazil. For. Ecol. Manag. 2010, 259, 1771-1785. [CrossRef]

17. Inail, A.M.; Hardiyanto, E.B. Growth of Eucalyptus pellita under different harvest residue management after three rotations of Acacia mangium at PT Musi Hutan Persada, South Sumatra. Technical Notes R\&D. PT Musi Hutan Persada 2021, 30, 1-8.

18. Inail, A.M.; Juniarso, S.; Pertiwi, P.S.; Al-Hanan, R.M. Litter decomposition of Eucalyptus pellita in Subanjeriji, South Sumatra. Technical Notes R\&D. PT Musi Hutan Persada 2021, 31, 1-5.

19. Adams, P.R.; Beadle, C.L.; Mendham, N.J.; Smethurst, P.J. The impact of timing and duration of grass control on growth of a young Eucalyptus globulus Labill. plantation. New For. 2003, 26, 147-165. [CrossRef]

20. George, B.H.; Brennan, P.D. Herbicides are more cost-effective than alternative weed control methods for increasing early growth of Eucalyptus dunnii and Eucalyptus saligna. New For. 2002, 24, 147-163. [CrossRef]

21. Little, K.M.; van Standen, J. Effect of vegetation control on Eucalyptus grandis x E. camaldulensis volume and economics. S. Afr. J. Bot. 2005, 7, 418-425. [CrossRef]

22. Little, K.M. Performance of Eucalyptus dunnii as influenced by vegetation control when felled at nine years in KwaZulu-Natal, South Africa. South. For. 2008, 70, 183-191. [CrossRef]

23. Garau, A.M.; Ghersa, C.M.; Lemcoff, J.H.; Barañao, J.J. Weeds in Eucalyptus globulus subsp. maidenii (F. Muell) establishment: Effects of competition on sapling growth and survivorship. New For. 2009, 37, 251-264. [CrossRef] 
24. Eyles, A.; Worledge, D.; Sands, P.; Ottenschlaeger, M.L.; Paterson, S.C.; Mendham, D.; O'Grady, A.P. Ecophysiological responses of a young blue gum (Eucalyptus globulus) plantation to weed control. Tree Physiol. 2012, 32, 1008-1020. [CrossRef]

25. Vargas, F.; Rubiar, R.; Gonzales-Benecke, C.A.; Sanchez-Olate, M.; Acaenana, P. Long-term response to area of competition control in Eucalyptus globulus plantations. New For. 2018, 49, 383-398. [CrossRef]

26. Nurudin, M.; Ohta, S.; Hardiyanto, E.B.; Mendham, D.S.; Wicaksono, A.; Heriyanto, J.; Watanabe, M. Relationships between soil characteristics and productivity of Acacia mangium in South Sumatra. Tropics 2013, 22, 1-12. [CrossRef]

27. Hardie, M.; Mendham, D.S.; Corkrey, R.; Hardiyanto, E.; Maydra, A.; Siregar, S.; Marolop, R.; Wibowo, A. Effects of eucalypt and acacia plantations on soil water in Sumatra. New For. 2018, 49, 87-104. [CrossRef]

28. Inail, A.M.; Supriadi, B.; Thaher, E.; Juniarso, S. Productivity of Clone Site Interaction Group 70 in Various Site Character. Technical Notes R\&D. PT Musi Hutan Persada 2019, 29, 1-5.

29. Inail, A.M.; Thaher, E. Potensi dan Respons Pemupukan Coppice di ex. Rotasi pertama Eucalyptus pellita. Technical Notes R\&D. PT Musi Hutan Persada 2021, 30, 1-5. (In Indonesian)

30. Inail, A.M.; Supriadi, B.; Thaher, E. Respon Berbagai Jarak Tanam dalam Memaksimalkan Produktivitas Eucalyptus pellita. Technical Notes R\&D. PT Musi Hutan Persada 2016, 26, 1-6. (In Indonesian) 